University of Nebraska - Lincoln

DigitalCommons@University of Nebraska - Lincoln

1980

\title{
Actinocyclus ingens var. nodus : a New, Stratigraphically Useful Diatom of the Circum-North Pacific
}

Jack G. Baldauf

USGS

John A. Barron

USGS

Follow this and additional works at: https://digitalcommons.unl.edu/usgsstaffpub

Part of the Earth Sciences Commons

Baldauf, Jack G. and Barron, John A., "Actinocyclus ingens var. nodus : a New, Stratigraphically Useful Diatom of the Circum-North Pacific" (1980). USGS Staff -- Published Research. 272.

https://digitalcommons.unl.edu/usgsstaffpub/272

This Article is brought to you for free and open access by the US Geological Survey at DigitalCommons@University of Nebraska - Lincoln. It has been accepted for inclusion in USGS Staff -- Published Research by an authorized administrator of DigitalCommons@University of Nebraska - Lincoln. 
Jack G. Baldauf

John A. Barron

U.S. Geological Survey

Menlo Park, California

\section{Actinocyclus ingens var. nodus: a new, stratigraphically useful diatom of the circum-North Pacific}

\author{
ABSTRACT \\ Actinocyclus ingens var. nodus Baldauf, \\ n. var., is a morphologically distinct \\ variety of the Miocene diatom $A$. ingens \\ Rattray. The last occurrence of this new \\ taxon approximates the top of the lower \\ Middle Miocene Denticula lauta Zone in \\ the circum-North Pacific. Its first occurrence \\ appears to be in the lower part of the \\ $D$. lauta zone and possibly lies close \\ to the Lower Miocene-Middle Miocene \\ boundary.
}

\section{INTRODUCTION}

Actinocyclus ingens Rattray (1890) is a common constituent of middle Miocene diatom assemblages throughout the world. It is recorded from broad areas of the North Pacific (Kanaya, 1971; Koizumi, 1973, 1975; Schrader, 1973, 1974; Barron, in press), from the equatorial Pacific (Gombos, 1975), from the North Atlantic (Schrader and Fenner, 1976; Bukry, 1978: Schrader, 1979), from the South Atlantic (Gombos, 1977: Fenner, 1978), and from Antarctic waters (McCollum, 1975: Schrader, 1976). The geologic range of $A$. ingens is generally considered to be late Early Miocene to Late Miocene (Barron, in press), although it occurs in Pliocene and Quaternary sediments off Antarctica, where it may be reworked (Schrader, 1976). Jousé (1977) considered the Antarctic form to be Coscinodiscus margaritaceous Castracane.

Rattray's (1890) type description of $A$. ingens states that the valve surface rises gradually from the center to its highest point, at about twofifths of the radius, then slopes down toward the border. Modern diatomists, however, have adopted a broad concept for $A$. ingens and have included specimens that have both flat and undulating valve surfaces (Koizumi, 1968, 1973; Kanaya, 1971: Gombos, 1977 ; Fenner, 1978). Furthermore, the pseudonodule of $A$. ingens is not easily observed, and specimens lacking a pseudonodule and otherwise referable to Coscinodiscus elegans Greville (1866) are often grouped with A. ingens (Kanaya, 1971). Coscinodiscus novazealandicus sensu Hanna (1932) is also referable to $A$. ingens.

Kanaya (1971) observed that concentric undulating valve surfaces are generally more pronounced on larger specimens of $A$. ingens, whereas smaller specimens tend to be flat. He further pointed out that specimens that best meet Rattray's type description are found among middle-sized specimens, but "they cannot be distinguished from others because of the presence of intermediate forms which connect individuals of various sizes in a continuous chain from one extreme to another." Numerous workers including Koizumi (1973), Gombos (1977), and Fenner (1978) have recognized such variations in the morphology of $A$. ingens and have followed Kanaya's (1971) reasoning for not subdividing the species.

In our studies of Miocene diatoms from the North Pacific area, we have also observed this wide variation in the morphology of $A$. ingens. We agree with Kanaya (1971) that specimens with an undulating valve surface and a depressed center show a gradation to flatter forms (pl. 1. figs. 1-4). We have also noted, however, that in some undulated specimens, the center of the valve rises to an equal elevation as the submarginal ring (pl. 1. figs. 5-9). This latter form of $A$. ingens probably 


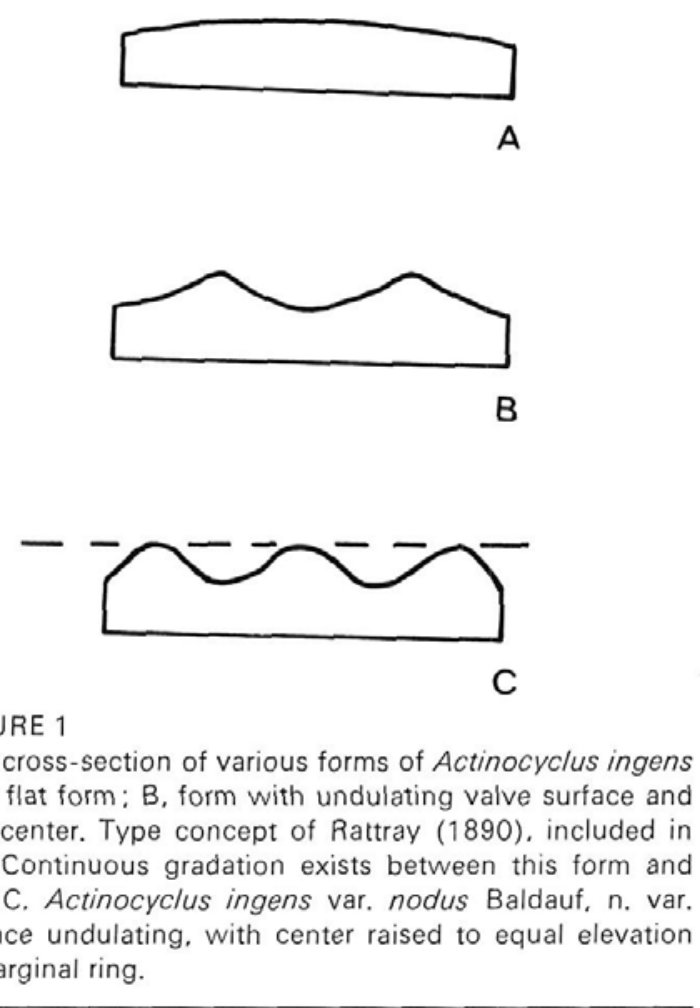

TEXT-FIGURE 1

Schematic cross-section of various forms of Actinocyclus ingens Rattray. A, flat form: B, form with undulating valve surface and depressed center. Type concept of Rattray (1890), included in this form. Continuous gradation exists between this form and flat form: C. Actinocyclus ingens var. nodus Baldauf, n. var. Valve surface undulating, with center raised to equal elevation with submarginal ring.

develops from other undulated forms; however, it is morphologically distinct and can easily be separated from them (text-fig. 1). Barron (in press) reported that this undulated form of $A$. ingens with a raised center may have stratigraphic utility in Miocene sediments off northeastern Japan. Consequently, this form is proposed below as a new variety of $A$. ingens, $A$. ingens var. nodus Baldauf, and its stratigraphic occurrence is documented in the Middle Miocene and Upper Miocene section exposed around Upper Newport Bay in Newport Beach. California.

\section{TAXONOMY}

Actinocyclus ingens var. nodus Baldauf, n. var.

Plate 1 , figures $5-9$

Actinocyclus ingens RATTRAY, in Jousé, 1977, pl. 53, fig. 1. Actinocyclus ingens variety 1.-BARRON, in press, pl. 5, figs. 8,12 .

Description: Valve circular, 35 to $65 \mu \mathrm{m}$ in diameter. concentrically undulated, with raised central and submarginal ring areas separated by a continuous depression. The central area is an areolated node covering approximately $1 / 5$ of the diameter. The width of the adjacent depression varies among specimens. The submarginal raised ring is distinct and is the same height as the central area.

Areolae are subrounded and arranged in radially lineate rows. Primary rows extend the length of the radius, whereas secondary rows extend from the depression
TABLE 1

Occurrence of Actinocyclus ingens var, ingens and $A$. ingens var. nodus, n. var. in samples from Upper Newport Bay section ( $\mathrm{A}=$ abundant, $\mathrm{C}=\mathrm{common}$. $F=$ few. $R=$ rare). Samples are those of Barron (1976).

\begin{tabular}{|c|c|c|c|}
\hline $\begin{array}{l}\text { Stratigraphic } \\
\text { Interval } \\
(\mathrm{m})\end{array}$ & Sample & $\begin{array}{l}\text { Actinocyclus } \\
\text { ingens } \\
\text { var, ingens. }\end{array}$ & $\begin{array}{c}\text { Actinocyclus } \\
\text { ingens } \\
\text { var. nodus }\end{array}$ \\
\hline 195 & NEW 61 & $\mathrm{~F}$ & \\
\hline 195 & UM & $\mathrm{R}$ & \\
\hline 192 & NE 20 & $\mathrm{~F}$ & \\
\hline 185 & NE 19 & $R$ & \\
\hline 184 & NEW 57 & A & \\
\hline 177 & NE 18 & $\mathrm{R}$ & \\
\hline 171 & NE 17 & $R$ & \\
\hline 169 & "NEW $51 "$ & $\mathrm{C}$ & \\
\hline 168 & NE 16 & $\mathrm{~F}$ & \\
\hline 160 & "NEW 48" & $\mathrm{F}$ & \\
\hline 158 & NE 15 & C & \\
\hline 151 & NE 14 & $\mathrm{~F}$ & \\
\hline 149 & NEW 42 & $\mathrm{~F}$ & \\
\hline 140 & $\operatorname{Tm} 19$ & $\mathrm{~F}$ & \\
\hline 122 & NE 13 & $\mathrm{R}$ & \\
\hline 115 & $\operatorname{Tm} 18$ & $R$ & \\
\hline 99 & NE 12 & $\mathrm{~F}$ & \\
\hline 95 & $\operatorname{Tm} 17$ & $\mathrm{~F}$ & \\
\hline 91 & NE 11 & $\mathrm{~F}$ & \\
\hline 78 & NE 10 & C & \\
\hline 75 & $\operatorname{Tm} 14$ & $A$ & \\
\hline 66 & $\operatorname{Tm} 9$ & $\mathrm{C}$ & $\mathrm{R}$ \\
\hline 55 & NE 9 & A & $\mathrm{F}$ \\
\hline 49 & NE 8 & A & $\mathrm{F}$ \\
\hline 32 & NE 7 & $\mathrm{~F}$ & $\mathrm{~F}$ \\
\hline 27 & NE 6 & $\mathrm{~F}$ & $\mathrm{~F}$ \\
\hline 21 & NE 5 & C & C \\
\hline 12 & NE 4 & $\mathrm{C}$ & $\mathrm{C}$ \\
\hline 9 & NE 3 & A & $\mathrm{F}$ \\
\hline 3 & NE 2 & C & $\mathrm{R}$ \\
\hline 0 & NE 1 & A & $\mathrm{R}$ \\
\hline 0 & NEW 5 & A & $\mathrm{R}$ \\
\hline
\end{tabular}

region to the margin. Areolae are larger ( 5 in $10 \mu \mathrm{m}$ ) in the central and submarginal ring zones and are surrounded by hyaline areas. Areolae decrease in size ( 9 in $10 \mu \mathrm{m}$ ) in the submarginal area, where they are indistinctly separated.

The pseudonodule near the margin is similar to that in Actinocyclus ingens Rattray, where it is described as obscure, sharply angular, with irregular edges (pl. 1. fig. 8).

Remarks: Actinocyclus ingens var. nodus Baldauf differs from $A$. ingens Rattray (1890) var. ingens by the presence of a raised central area, which is equal in height to the raised submarginal ring. Rattray's (1890) type concept of $A$. ingens includes specimens with depressed center and raised submarginal rings (see text-fig. 1).

Etymology: nodus (Latin), knot or swelling.

Occurrence: Presently known only from the circumNorth Pacific, lower Middle Miocene, Denticula lauta Zone of Koizumi (1975), North Pacific diatom Zones XXIII-XXI of Schrader (1973).

Holotype: USNM 689949, sample NE 9 (of Barron, 1976) (55 m). Monterey shale, Upper Newport Bay. 


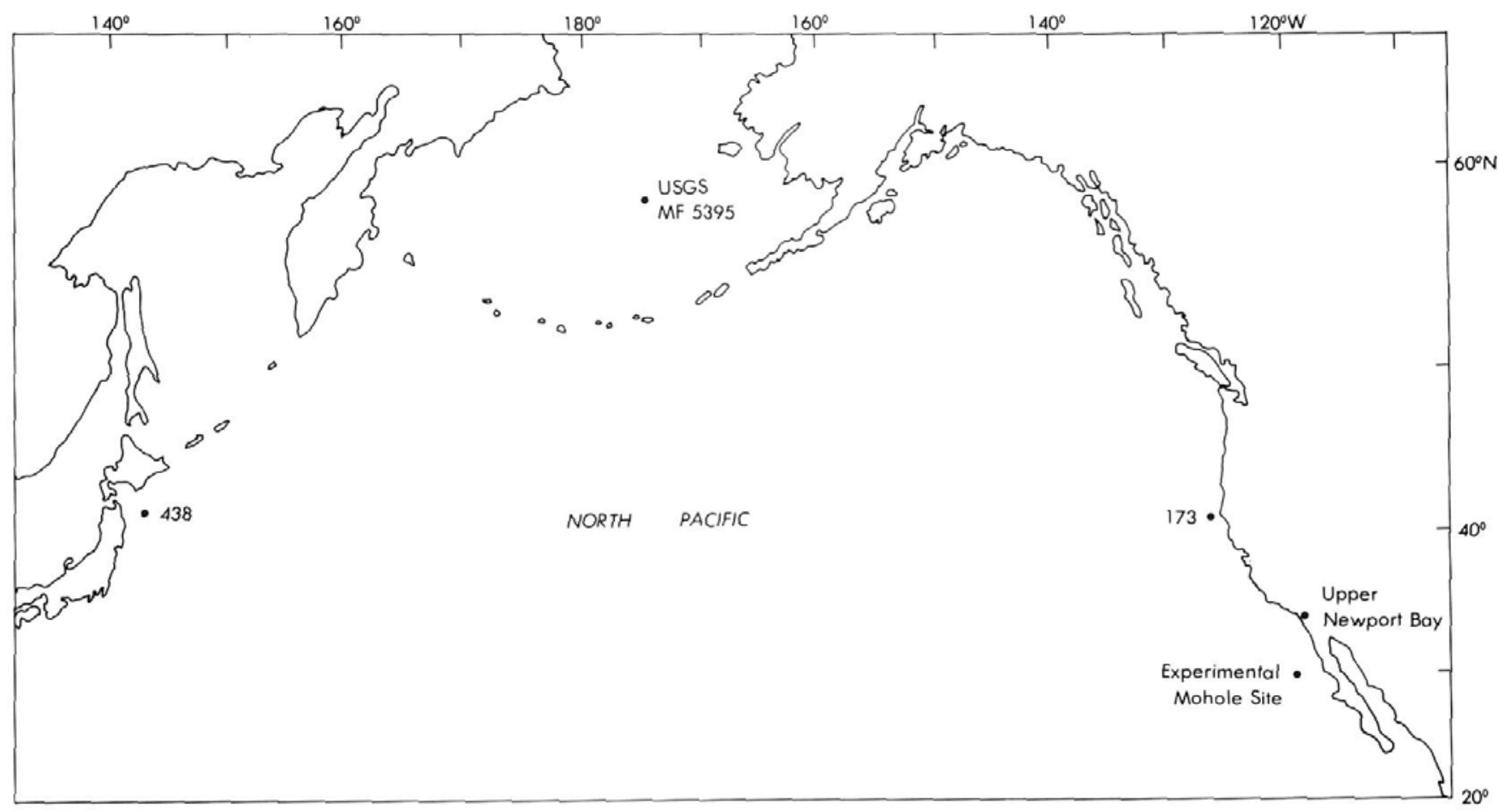

TEXT-FIGURE 2

Map of high-latitude North Pacific showing location of various sections discussed.

Newport Beach, California (pl. 1, fig. 7). Size $64 \mu \mathrm{m}$ in diameter.

Isotypes: USNM 689950 to 689952.

STRATIGRAPHIC OCCURRENCES IN THE UPPER NEWPORT BAY SECTION

Abundant and well-preserved Middle Miocene to Early Pliocene diatoms are documented by Wornardt (1973) and Barron $(1975,1976)$ in exposures of the Monterey Shale around Upper Newport Bay in Newport Beach, California (text-fig. 2). Within this section, Barron (1976) recorded Actinocyclus ingens as most common and consistent in the lower part (middle Miocene to upper Miocene). which is exposed on the eastern side of the bay. This part of the section includes the samples from which $A$. ingens var. nodus has been described. In order to document the stratigraphic range of $A$. ingens var. nodus at Upper Newport Bay, the 32 samples of Barron (1976) were reexamined.

The stratigraphic occurrences of Actinocyclus ingens var. ingens and $A$. ingens var. nodus in these samples are shown in table 1. An entire microscope slide $(22$ $X 40 \mathrm{~mm}$ cover glass size) of unsieved acid residue was examined under the light microscope at X 500 . Specimens were recorded as "abundant" if at least 1 individual was present in each field of view: "common" if 1 individual was encountered in 5 fields of view; "few" if present in each horizontal traverse (length $40 \mathrm{~mm}$ ); and "rare" if there were sparser occurrences.

Actinocyclus ingens var. nodus ranges from the base of the section (sample NEW 5) to a horizon $66 \mathrm{~m}$ above the base (sample Tm 9). Therefore, A. ingens var. nodus ranges from North Pacific diatom Zone XXIII to the top of North Pacific diatom Zone XXI of Barron (1976). Barron (1976) assigned this interval to the lower Middle Miocene, and Warren (1972) placed the benthic foraminifers of this interval within the upper part of the provincial benthic foraminiferal Luisian Stage (text-fig. 3). Although not recorded in table 1, we observed that undulated specimens of $A$. ingens, in general, are also restricted to the lower parts of this section. This supports Kanaya's (1971) observation that undulated specimens of $A$. ingens do not occur above the Middle Miocene in the Experimental Mohole Drilling Site section off Baja California, Mexico $\left(28^{\circ} 59^{\prime} \mathrm{N}, 117^{\circ} 30^{\prime} \mathrm{W}\right)$.

\section{UPDATED DIATOM BIOSTRATIGRAPHY AT UPPER NEWPORT BAY}

Barron (in press) defined biostratigraphic subzones for the high-latitude North Pacific diatom zonation of Koizumi (1975) that can be recognized throughout the middle- and high-latitude North Pacific for the Middle and Upper Miocene. In many cases the boundaries of these subzones were chosen so that they 
Stratigraphic ranges of diatom taxa

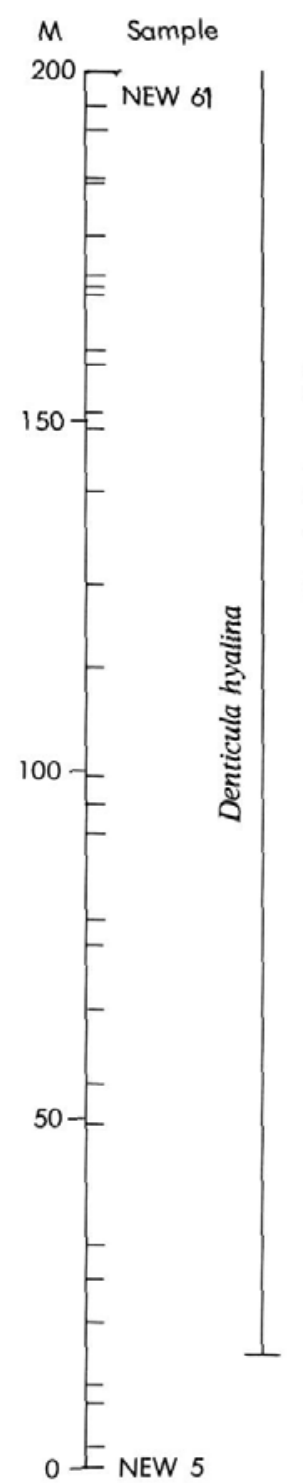

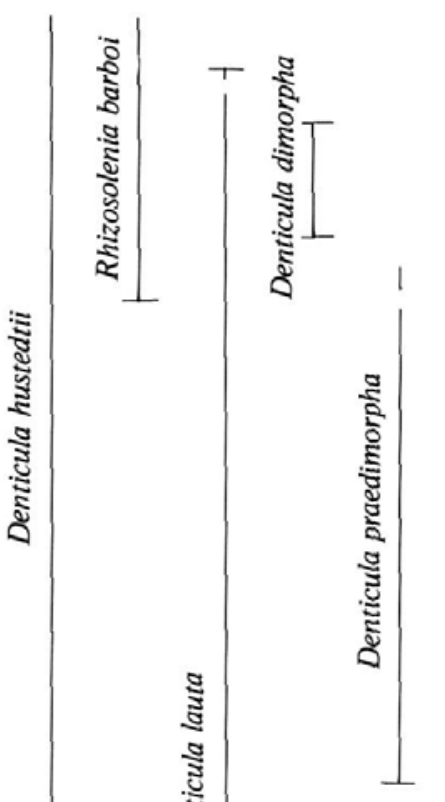

$\perp$

TEXT-FIGURE 3

Stratigraphic section at Upper Newport Bay showing stratigraphic position of samples studied (Barron. 1976) and ranges of selected diatoms including Actinocyclus ingens var. nodus. Right side of figure, diatom biostratigraphy of this report (left column) listed with that of Barron (1976) and benthic foraminiferal biostratigraphy of Warren (1972).

corresponded with zonal boundaries of the North Pacific diatom zonation of Schrader (1973) and Barron (1976).

As a part of this study, samples from the lower section at Upper Newport Bay have been reexamined and correlated with Barron's (in press) refinement of Koizumi's (1975) diatom zonation (text-fig. 3). Whereas Barron (1976) recorded Denticula hustedtii Simonsen and Kanaya as ranging to the base of the Upper Newport Bay section, we did not observe this taxon below sample NE $10(78 \mathrm{~m})$. Specimens from below

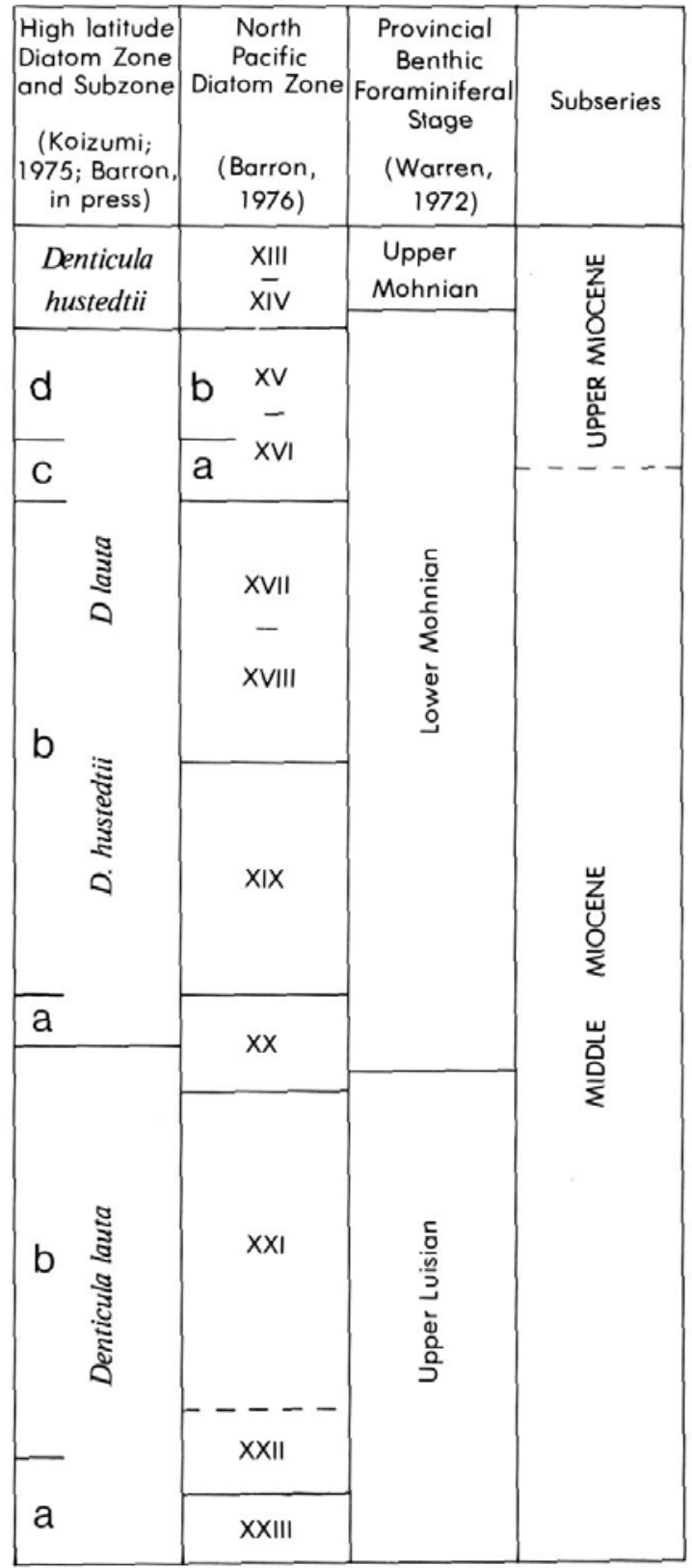

$78 \mathrm{~m}$ that were assigned to $D$. hustedtii by Barron (1976) are here reassigned to D. lauta Bailey. Another difference from the results of Barron (1976) regards the range of Denticula dimorpha Schrader. Akiba (1979) recently separated from this species specimens in which the crossbars are not united to the septum. $\mathrm{He}$ included such specimens in the new species $D$. praedimorpha Akiba (1979). Following Barron's (in press) zonation, the first occurrence of $D$. praedimorpha at $91 \mathrm{~m}$ in the Upper Newport Bay section marks the base of Subzone b of the Denticula hustedtiiDenticula lauta Zone, and the first occurrence of $D$. 
dimorpha s. str. at $169 \mathrm{~m}$ marks the base of Subzone $\mathrm{d}$ of the $D$. hustedtii-D. lauta Zone (text-fig. 3). Barron (in press) places the middle Miocene-upper Miocene boundary of Ryan and others (1974) in Subzone c of the $D$. hustedtii- $D$. lauta Zone. The lowest part of the Upper Newport Bay section, including the entire local range of $A$. ingens var. nodus, is divided into Subzones a and b of the Denticula lauta Zone by the first occurrence of $D$. hyalina Schrader in sample NE $4(12 \mathrm{~m})$.

\section{OCCURRENCES ELSEWHERE IN THE CIRCUM-NORTH PACIFIC}

At Deep Sea Drilling Site 438 (lat. $40^{\circ} 37.79^{\prime}$ N, long. $143^{\circ} 14.15^{\prime}$ E) (text-fig. 2), Barron (in press) recorded that specimens synonymous with Actinocyclus ingens var, nodus ( $A$. ingens var. 1 of Barron, in press) range from about $821 \mathrm{~m}$ to $689 \mathrm{~m}$ in the section. The lowest occurrence is in the lower part of the Denticula lauta Zone (Subzone a) and probably lies close to the Lower Miocene-Middle Miocene boundary (Barron, in press), but poor to moderate preservation in that interval makes it doubtful whether this is a true first occurrence. The highest occurrence of $A$. ingens var. nodus is immediately below the first common occurrence of Denticula hustedtii, a horizon which probably correlates with the first occurrence of $D$. hustedtii at Upper Newport Bay and in the low-latitude North Pacific (DSDP Site 77). Denticula hustedtii first occurs at $699 \mathrm{~m}$ in the section at Site 438, so that the overlap of the ranges of $A$. ingens var. nodus and $D$. hustedtii is about $10 \mathrm{~m}$.

Samples from DSDP Site 173 (lat. $39^{\circ} 57.71^{\prime} N$, long. $125^{\circ} 27.12^{\prime} \mathrm{W}$ ) off the northern California coast (textfig. 2) were examined briefly, and $A$. ingens var. nodus was observed in Cores 28 and 29 (252.0-271.5 m). This interval is assigned to North Pacific diatom zones XXIII and XXII by Schrader (1973) and to the Denticula lauta Zone by Koizumi (1977).

Finally, Actinocyclus ingens var. nodus has been recorded in material dredged from the Bering Sea (sample USGS Mf5395) (lat. $57^{\circ} 53^{\prime} \mathrm{N}$, long. $174^{\circ} 22.3^{\prime} \mathrm{W}$ ) that is correlated with the Denticula lauta Zone (Barron, unpublished data, 1979) (textfig. 2).

The last occurrence of Actinocyclus ingens var. nodus thus approximates the top of the Denticula lauta Zone of Koizumi (1975) in the North Pacific. Relationships at Upper Newport Bay show that it is close to the boundary between the Luisian and Mohnian provincial benthic foraminiferal stages of California. Data from DSDP Site 438 imply that the first occurrence of $A$. ingens var. nodus is within the lower part of the $D$. lauta Zone : however, this requires further documentation.
Warren (1972) reported that the top of the Sphenolithus heteromorphus nannofossil zone is close to the Luisian-Mohnian boundary in the Upper Newport Bay section, and, therefore, it approximates the top of the Denticula lauta Zone in that section (text-fig. 3 ). Unpublished data acquired by Barron and David Bukry during DSDP Leg 63 off southern California and Baja California also show that the top of the $D$. lauta Zone correlates fairly closely with the top of the Sphenolithus heteromorphus Zone of Bukry (1973). Koizumi (1977) estimated that the absolute age of the top of the $D$. lauta Zone is about $14.0 \mathrm{Ma}$ (million years before present) on the basis of a radiometric date from Japan. This is in good agreement with Bukry's (1975) estimate of $14.0 \mathrm{Ma}$ for the top of the S. heteromorphus Zone. Relationships at Upper Newport Bay and at Site 438 consequently suggest that the last occurrence of $A$. ingens var. nodus is at about 14.0 Ma in the North Pacific.

Actinocyclus ingens is a fairly robust, dissolutionresistant species. It is commonly one of the few species remaining in strongly dissolved Middle Miocene assemblages (Barron, unpublished data, 1979). Actinocyclus ingens var. nodus, therefore, is likely to be a valuable taxon for correlating dissolved sequences with the D. lauta Zone.

In summary. Actinocyclus ingens var. nodus is morphologically distinct and is stratigraphically useful in the lower Middle Miocene of the circum-North Pacific. Whether $A$. ingens var. nodus is present or stratigraphically useful in areas outside the North Pacific awaits future study.

\section{ACKNOWLEDGMENTS}

The manuscript was reviewed by David Bukry and R. Z. Poore of the U.S. Geological Survey. We thank Lloyd Burckle for his helpful comments, and further acknowledge the assistance of William V. Sliter and Kristin McDougall. We thank Rose Trombley for the typing, and Robert Oscarson for the scanning electron microscopy. Deep Sea Drilling Project samples were supplied through the assistance of the U.S. National Science Foundation.

\section{REFERENCES}

AKIBA, F., 1979. The morphologies of Denticula dimorpha and its allied species, and the Neogene diatom biostratigraphy of Japan. Rept. Tech. Lab. JAPEX, 22(3) : 148-189.

BARRON, J.A., 1975. Late Miocene-Early Pliocene marine diatoms from southern California. Palaeontographica, 151 (B) :97-170.

1976. Revised Miocene and Pliocene diatom biostratigraphy of Upper Newport Bay. Newport Beach, California. Marine Micropal., 1: 27-63. 
- in press. Miocene to Quaternary diatom biostratigraphy of DSDP Leg 57, off northeast Japan. In: von Huene, R., and Nasu, N., Initial reports of the Deep Sea Drilling Project, volume 57. Washington, D.C.: U.S. Government Printing Office.

BUKRY, D., 1973. Low-latitude coccolith biostratigraphic zonation. In: Edgar. N. T., Saunders, J. B., et al.. Initial reports of the Deep Sea Drilling Project, volume 15:685-703. Washington, D.C.: U.S. Government Printing Office.

1975. Coccolith and silicoflagellate stratigraphy, northwestern Pacific Ocean. Deep Sea Drilling Project Leg 32. In: Larson, R. L., Moberly, R., et al., Initial reports of the Deep Sea Drilling Project, volume 32 :677-701. Washington, D.C.: U.S. Government Printing Office.

1978. Cenozoic silicoflagellate and coccolith stratigraphy, northwestern Atlantic Ocean, Deep Sea Drilling Project Leg 43. In: Benson, W. E., Sheridan, R. E., et al., Initial reports of the Deep Sea Drilling Project. volume $44: 775-806$. Washington, D.C.: U.S. Government Printing Office.

FENNER, J., 1978. Cenozoic diatom biostratigraphy of the equatorial and southern Atlantic Ocean. In: Supko, P. R., Perch-Nielsen, K., et al., Initial reports of the Deep Sea Drilling Project, v. supplement 38-41:491-623. Washington, D.C.: U.S. Government Printing Office.

GOMBOS, A. M., JR., 1975. Fossil diatoms from Leg 7. Deep Sea Drilling Project. Micropaleontology, 21(3) : 306-333.

1977. Paleogene and Neogene diatoms from the Falkland Plateau and Malvinas Outer Basin, Leg 36. Deep Sea Drilling Project. In: Barker, P. F., Dalziel, I. W. D.. et al., Initial reports of the Deep Sea Drilling Project, volume 36:575-688. Washington, D.C.: U.S. Government Printing Office.
GREVILLE. R. K., 1866. Descriptions of new and rare diatoms from the tropics and Southern Hemisphere. Bot. Soc. Edinburgh. Trans., 8: 436-441.

HANNA, G. D., 1932. The diatoms of Sharktooth Hill, Kern County. California. California Acad. Sci., Proc., 4th ser.. 20(6): 161-263.

JOUSÉ, A. P. (Ed.), 1977. Atlas of microorganisms in bottom sediments of the oceans: Diatoms, radiolaria, silicoflagellates, and coccoliths. Nauka, Moscow.

KANAYA, T., 1971. Some aspects of pre-Quaternary diatoms in the oceans. In: Funnell, B. M., and Riedel, W. R., eds., The micropaleontology of oceans. London: Cambridge Univ. Press : $545-565$, pls. 40.1-40.6.

KOIZUMI, I., 1968. Tertiary diatom flora of Oga Peninsula, Akita Prefecture, northeast Japan. Tohoku Univ., Sci. Repts., ser. 2 (Geol.), 40 : 171-240, pls. 32-35.

1973. The Late Cenozoic diatoms of Sites 183-193. Leg 19. Deep Sea Drilling Project. In: Creager, J. S., Scholl, D.W., et al.. Initial reports of the Deep Sea Drilling Project, volume $19: 805-855$. Washington, D.C.: U.S. Government Printing Office.

1975. Late Cenozoic diatom biostratigraphy in the circumNorth Pacific region. Geol. Soc. Japan Jour., 81 : 611-627.

1977. Diatom biostratigraphy in the North Pacific region. Internatl. Congr. Pacific Neogene Stratigraphy, 1st, Tokyo 1976, Proc., p. 235-253.

\section{1-4 Actinocyclus ingens Rattray var. ingens} Gradation from flat forms (fig. 4) through forms with increasingly undulated valve surfaces (figs. 1-3). 1, sample USGS Mf5395, Bering Sea, scale bar equals $12 \mu \mathrm{m}$. This specimen closely approximates the type concept of Rattray (1890) : 2. sample NE9. Newport Beach, California, scale bar equals $12 \mu \mathrm{m}$; 3, sample Tm9, Newport Beach, California, scale bar equals $3 \mu \mathrm{m} ; 4$, sample NE1. Newport Beach, California, scale bar equals $3 \mu \mathrm{m}$.

5-7 Actinocyclus ingens var. nodus Baldauf, $n$. var. 5, isotype USNM 689950, sample NE9, Newport
Beach, California. Scale bar equals $12 \mu \mathrm{m} ; 6$, Deep Sea Drilling Project, sample 438A-70-5, 121-123 cm. Scale bar equals $12 \mu \mathrm{m}$; 7, holotype USNM 689949, sample NE9, Newport Beach, California. Diameter $64 \mu \mathrm{m}$.

8-9 Scanning electron micrographs of Actinocyclus ingens var. nodus.

Specimens show that center of valve is raised to same height as submarginal ring. Monterey shale, Newport Beach, California. 8, isotype USNM 689951, sample NE3. Pseudonodule near 12 o'clock position: 9, isotype USNM 689952. sample NE3. 

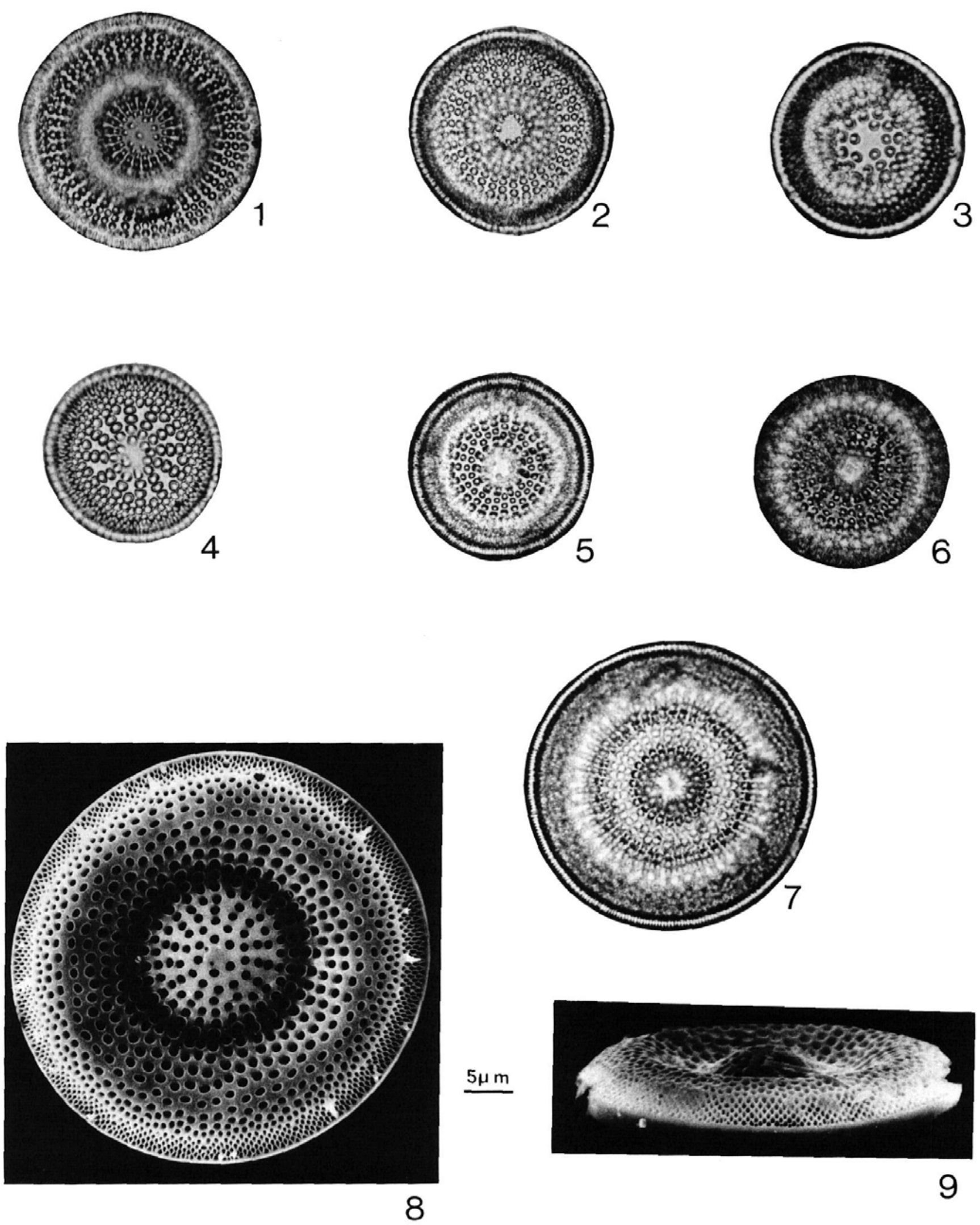

9 
McCOLLUM, D.W., 1975. Diatom stratigraphy of the southern ocean. In: Hayes, D., Frakes, L. A., et al., Initial reports of the Deep Sea Drilling Project, volume 28:515-571. Washington. D.C. : U.S. Government Printing Office.

RATTRAY, J. 1890. A revision of the genus Actinocyclus Ehrenberg. Quekett Micr. Club, Jour., ser. 2, 4:137-212, pl. 11.

RYAN, W. B. F., CITA, M. B., RAWSON, M., BURCKLE, L. H., and SAITO, T., 1974. A paleomagnetic assignment of Neogene stage boundaries and the development of isochronous datum planes between the Mediterranean, the Pacific and Indian Oceans in order to investigate the response of the world ocean to the Mediterranean "salinity crisis." Riv. Italiana Pal., $80: 631-688$.

SCHRADER, H.-J. 1973. Cenozoic diatoms from the Northeast Pacific, Leg 18. In: Kulm, L. D., von Huene, R., et al., Initial reports of the Deep Sea Drilling Project, volume 18:673-797. Washington, D.C. : U.S. Government Printing Office.

1974. Revised diatom stratigraphy of the Experimental Mohole Drilling. Guadalupe Site. California Acad. Sci., Proc., ser. 4, 39:517-562.

1976. Cenozoic planktonic diatom biostratigraphy of the southern Pacific Ocean. In: Hollister, C. D.. Craddock, C., et al., Initial reports of the Deep Sea Drilling Project, volume 35 : 605-672. Washington. D.C.: U.S. Government Printing Office.
1979. Opal phytoplankton in DSDP Leg 49 samples. In: Luyendyk, B. P.. Cann, J. R., et al., Initial reports of the Deep Sea Drilling Project, volume 49:589-593. Washington, D.C.: U.S. Government Printing Office.

SCHRADER, H.-J, and FENNER, J., 1976. Norwegian Sea Cenozoic diatom biostratigraphy and taxonomy. In: Talwani. M., Udintsev. G., et al., Initial reports of the Deep Sea Drilling Project, volume 38:921-1099. Washington, D.C.: U.S. Government Printing Office.

WARREN. A. D., 1972. Luisian and Mohnian biostratigraphy of the Monterey Shale at Newport Lagoon, Orange County, California. In: Stinemeyer, E. H., ed., Pacific coast Miocene biostratigraphic symposium. Soc. Econ. Paleontologists and Mineralogists, Proc., Pacific Section, Bakersfield, Calif. : 27-36.

WORNARDT, W. W., JR. 1973. Diatom, silicoflagellate, radiolarian, calcareous nannofossil, and foraminiferal biostratigraphy of the Middle and Late Miocene and Pliocene of Newport Back Bay. Newport Beach, California. Guidebook SEPM Trip 1. Miocene and sedimentary environments and biofacies. southeastern Los Angeles Basin. Amer. Assoc. Petr. Geol., Soc. Econ. Paleontologists and Mineralogists, Soc. Explor. Geophysicists, 1973 Ann. Mtg. : 39-53.

Manuscript received June 27, 1979. 